\title{
The Effect of Transformational Leadership, Self Efficacy and Self Learning toward Lecturers Job Performance at STAIN Curup Rejang Lebong Regency of Bengkulu Province
}

\author{
Jumira Warlizasusi ${ }^{1}$, Yetti Supriyati ${ }^{2}$ Neti Karnati $^{3}$ \\ ${ }^{1}$ Doctoral Program of Education Management, Jakarta State University \\ ${ }^{1}$ Lecturer of IAIN Curup, Bengkulu, Indonesia \\ ${ }^{2}$ Lecturer, Universitas Negeri Jakarta, Indonesia \\ ${ }^{3}$ Lecturer, Universitas Negeri Jakarta, Indonesia
}

\begin{abstract}
This research aims to analyze direct effect of transformational leadership, self efficacy and self learning toward lecturers Job performance at STAIN Curup. This research is newest research by using research model about lecturer's performance which was surveyed from the effect of transformational leadership (indicators: effectiveness, productivity and usefulness), self efficacy factors (indicators: mobilize motivation, cognitive resource, job difficulty level and attitude selection), and self learning (indicators: self assesment, self improvment and self reinforcement). This research used quantitative approach with survey method and path analysis technique. Population was 96 civil servant lecturers. Findings of the research showed that there is a positive effect of transformational leadership toward lecturer's job performance with value of 0.2390 , positive effect self efficacy and lecturers job performance with value of 0.3040 and positive effect of self-learning torward lecturers job performance with value of 0.2720 , there is also dirrect effect of transformational leadership toward self learning with value of 0.2740 , self efficacy toward self learning with value of 0.4920 , and transformational leadership toward self efficacy with value of 0.2670 .
\end{abstract}

Keywords: Transformational leadership, self efficacy, self learning, lecturers job performance.

\section{Introduction}

Lecturer is one of the essential components in educational system at higher education which required professional, good pervormance, integrity and high dedication toward their profession. In principally, lecturers belong to quite high potency to be creative in improving their performance. Nevertheless, their potency to improve job performace is not always well developed and smootly caused by several factors come up either from their inside or outside. This is as stated in regulations number 12 year of 2012 that lecturer is professional educator and scientist with major duty: develop, disseminate science and transform science and technology under education, research, and community services, should be able to implement the performace properly and correctly by tridharma higher education as mentioned regulations.

State College of Islamic Stuides (STAIN) Curup is the only one of Islamic Higher Education in Rejang Lebong Regency of Bengkulu Province. Challenges faced this Islamic State Higher Education of Curup is quite hard and graduate quality expected is quite high. Therefore, It needs solutions which enable STAIN Curup to capable of overcoming the problems. Hence, whole challenges and potency owned STAIN Curup undertakes step strategically with focus on leadership, good lecturers performance, good climate and cultural organization,effective human resources as well as strong motivation of achievement as implementation to formulate focus, way, and complete substance in education field. Fundamental problem of STAIN Curup is its low job performance quality, quality of higher education and leader as well as lecturers quality as determinant factors of the problem. For these reasons, it needs to study deeply because by doing this 
research expected to find, reveal factual and empirical information which able to explain the problems of management process at higher education related to lecturer job performance. Gibson et al. (2012) states that job performance is the outcome of jobs that related to the purposes of the organization such as quality, efficiency, and other criteria of effectiveness. Lecturers job performance determined and influenced manager and lecturer effectiveness in carring out the function of management at study program that concern with arrangement such as functional planning, organizing and controling toward implementation of tridharma higher education (education, research and community services), lecturers productivity in implementing tridharma higher education and their quality in running their job. Transformational leadership factors is one of main factors in leading future institution for improving lecturer quality. A Lecture needs guidance and direction from his leader in running his job effectively and efficiently. Colquitt (2011:475) points out that it turns out that the full spectrum of transformational leadership can be summarized using four dimensions: idealized insfluence, inspirational motivation, intellectual stimulation, and individualized consideration. A Leader should able to be change agent for mobilizing positive transformation in Campus environment. In this case, lecturer should be driven to follow environment dynamics in order away from lag of improvement in outside organization. Sometimes, lecturer does not feel noted by his leader. Another factor is self efficacy with indicators: mobilize motivation, cognitive resources, task difficulty level and attitude selection includes competency, motivation and honesty. Accordance with Robert Kreitner and Angelo Kinicky difines self efficacy is a person belief about his or her chance of succesfully accomplish in specific task. Self efficacy improved strongly anable someone in taking action particularly on special jab faced to gain aims wanted. In this context appears question of is someone seek at himself confidence and friendly or shy and afraid of facing others. Another factors is self learning. A Shani (2009: 29) point out self-learning is related to selfmotivation, self-awareness, and self-control. It presupposes that the learners are interested in learning. Further, knowing yourself and having the ability for planning and a sense of commitment seem critical. For knowing self efficacy, a lecture applies: self assesment, self improvment and self reinforcement.

\section{Objectives}

This research aims to analyze dirrect effect of transformational leadership toward job performance, dirrect effect of self efficacy toward job performance, dirrect effect of transformational leadership toward self learning, the effect of self efficacy toward self learning and dirrect effect of transformational leadership toward self efficacy of lecturers at STAIN Curup.

\section{Literature Review \\ Job performance}

Colquitt, LaPine and Welson (2011: 32) define job performance is formally defined as the value of the set of employee behavior that contribute, either positively or negatively, to organizational goal accomplishment. However, the reach the aims is quite hard, even there are many civil servant with lower job performance inspite of alraedy having training and resources on it to improve ability and motivate their job performance. Ivancevich, Konopaske dan Matteson (2014: 172) said that job performance is a set of employee work related behaviors designed to accomplish organizational goals. A link with Rue, Ibrahim and Byars (2008: 222) states that job performance is the net of an employee's effort as modified by abilities and role (or task) perceptions. Thus performance in a given situation can be viewed as resulting from the inter-relationship. Motowidlo et al in Thushel Jayawheera (2005: 271) defines job performance is define as behaviors or activities that are performed towards achieving the organization goals and objectives. Contextual job performance consists of attitude indirrectly contributes to job performance of organization, but support organization, social and psychology of environment. Austin and Villanova in Visesran and Denis states that. Campbell in Jex and Britt (2008: 97) also mentions that job performance should be distinguished from effectiveness, productivity and utility. Effectiveness is defined as the evaluation of the results of an employees job performance. This is important distinction because employee effectiveness is determined by more than just job performance. Productivity is closely related to both performance and effectiveness, but different because productivity takes into account the cost of achieving a given level of performance or effectiveness. Finally, utility represents the value of a given level of performance, effectiveness, or productivity for the organization. Utility is somewhat different, however. An employee may achieve a high level of effectiveness. 
The excerpt of concepts above can be synthesized that job performance is job demonstration of someone to finishhis task and responsibility based on ability and skills with indicators to asses job performance is effectiveness, productuvity and usefulness.

\section{Transformational Leadership}

Gary Yukl (2001: 264) defines transformational leadership were defined in terms of the component behavior used to influence follower and the effects of the leader on followers. A line with this, Mc.Shane dan Glinov (2015: 244) determines transformational leadership is a leadership perspective that explains how leaders change teams or organizations by creating, communicating, and modeling a vision for the organization or work unit and inspiring employees to strive for that vision. Furthermore, Colquitt et al. (2011: 475) states transformational leadership is viewed a more motivational approach than other managerial approaches. Transformational leaders motivates their followers and make civil servant consciously about how importent of task result, mobilize them to exceed self interest for organization or team. Emma Soane (2015: 67) points out that transformational leadership is complemented by one positive form of transactional leadership: contingent reward involves giving followers rewards for fulfilling obligations. Richard Daft (2015: 360) defines transformational leadership is characterized by the ability to bring about significant change in both followers in and the organization. Transformational leaders have the ability to lead changes in and organization's vision, strategy and culture as well as promote innovation in products and technologies. Ttransformational leaders have ability to conduct change on vision, strategy and cultural organization as well as promote innovation in product and technology. A line with this, James L Gibson, Donnely, Ivancevich dan Konopaske (2012: 356) defines transformational leadership is ability to inspire and motivate followers to achieve results greater than originally planned for internal reward. Further, Colquitt stated that it turns out that the full spectrum of transformational leadership can be summarized using four dimensions: idealized influence, inspirational motivation, intellectual stimulation, and individualized consideration.

From the explanation of concepts above can be synthesized that transformational leadership is attitude of leader in influencing his subordinates in running their task in order belong to desire for warking as effort to gain organization aims with indicators used to asses job performance is idealism effect (give example and have capacity to manage organzation change to followers), intelectual stimulation (mobilize innovation and creativity), inspirational motivation (carry on empowerment and inspire subordinates) and individual consideration (individual consideration become supervisor and trainer for subordinates by doing mentoring).

\section{Self Efficacy}

Theory of self efficacy formerly carried out by psychologists from Stanford University, they were Albert Bandura.Gibson, Donnely, Ivancevich and Konopaske (2011: 160) who states that self-efficacy is belief that one can perform adequately in a situation. Has three dimensions magnitude, strength and generality. Robert Kreitner and Angelo Kinicky $(2010,207)$ defines self-efficacy is a person belief about his or her chance of successfully accomplish in specific task. A line with this, Fred (2010: 202) points out that self-efficacy is state like and therefore is aimed at specific tasks and open to training and development. Jennifer M. George and Gareth R Jones (2005) maintain that self-efficacy is a person's belief about his or her ability to perform a particular behavior successfully. In accordance with Schermerhorn, Osborn, Uhl Biene and Hunt (2012: 88) states that self-efficacy is a person's that she or he is capable of performing a task". Hereinafter, it is also said that people with high self-efficacy believe that they have the necessary abilities for a given job, that they are capable of the effort required, and that no outside events will hinder them from attaining their desired performance. Bandura in Schermerhorn's book mentions that self-efficacy is defined as people's judgments of their capabilities to organize the execute course of action required to attain designated types of performance. Further explanation is from Gibson (2012: 160) points out that self-efficacy has three dimension: magnitude, the level of task difficulty a person believes she can attain; strength, referring to the conviction regarding magnitude as strong or weak; and generally, the degree to which the expectation is generalized across situations. An employee's sense of capability influences his perception, motivation and performance. Bandura in Fred Luthans (2010: 205) also maintains that people of high efficacy focus on the opportunities worth pursuit, and view obstacles as surmountable. Through ingenuity and perseverance they figure out ways of exercising some control even in environment of limited opportunities and many constraints. Those beset with self doubts dwell on impediment which they can exert little control, and easily 
convince themselves of the futility of effort. They achieve limited success even in environments that provide many opportunities. Next, Stephen Robbin and Judge (2010: 251) explain that the higher yourself efficacy, the more confidence you have in your ability to succeed. So, in difficult situations, people with low self efficacy are more likely to lessons their effort or give up together, while those with high self-efficacy will try harder to master the challenge. Build upon experts view points above, so it can be synthesized that self efficacy is human attitude, human cognition and environment which all of them interact by the way of effect one another toward their capacity and success in carring out main task and function as in tridharma higher education with indicators: mobilize motivation, cognitive resources, task difficulty level and attitude selection.

\section{Self Learning}

Shani (2009:29) defines that self learning is related to self motivation, self awareness, and self control. It presupposes that the learners are interested in learning. Further, knowing yourself and having the ability for planning and a sense of commitment seem critical. A line with this, Daft (2015: 458) states that self learning is an individual's personality is the set of characteristics that underlie a relatively stable pattern of behavior in response to ideas, objects, or people in the environment. Independent phenomenon in learning (self learning) explaned in many literatures by using label or concept of independent learning . Sharon Zumbrun, Joseph and Elizabeth (2011:4) point out that self regulated learning is a process that assists students in managing their thoughts, behaviors and emotions in order to successfully navigate their learning experiences. This process occurs when a students purposefully actions and processes are directed towards the acquisition of information or skills. Further, Woolfolk difines that environmental events, personal factors, and behaviors are seen as interacting in the process of learning. Personal factor (beliefs, expectations, attitudes, and knowledge), the physical and social environment (resources, consequences of actions, choices, and verbal statements) all influence and are influenced by each other. Woolfok states that a teacher should have self learning in order anable to learn lifetime to improve himself. Self learning has skill combination learning academic and self restoration that makes the learner feels easier and motivated. Self learning transform whatever mental abilities becomes skills and strategies. The concept of self learning integrates many things which has been known about effective learning and motivation. A lecturer motivate his inside needs knowledge, task, strategies to learn and contexts of learning will be applied. For knowing self learning, a lecturer makes self assesment, namely doing observation to his attitudes. This is alike with making self assesment or self reflection. Self reflection will grow self learning, one of them is new ideas of something happened to be a lesson. A lecturer in improving self learning is under motivate himself to be the best one. Based on conceptual description above, it can be synthesized that self learning is individual effort done sistematically for focusing mind, feeling and attitude to gain learning aim applied to himself by making improvements consciously and planned even motivate himself to progress becomes better by maintaining supporting ways to improve optimally. This is assesed based on indicators: self assesment, self improvement and self reivorcement).

\section{The Effect of Transformational Leadership toward Job Performance}

Transformational leaders can motivate their subordinates by making civil servant more conscious about the important of job performance. This action enables to mobilize them in exceeding their self interest for organization. In accordance with Jason A. Colquitt, Jeffrey A. Lepine, Michael J. Wesson (2011: 483) maintain that transformational leadership has a moderate positive effect on performance. Employee with transformational leaders tends to have higher levels of task performance. They are also more likely to engage in Citizenship Behavior. Less is known about the effective of transformational leadership on counterproductive behavior. Christopher Achua and Lussier (2011: 304) stated that transformational leadership describes processes of positive influence that changes and transforms individuals, organizations, and communities. Research studies have consistently revealed that transformational leadership is positively related to individual, group, and organizational performance. Based on explanation above, it can be comprehended that transformational leader is very affected toward job performance of subordinates in order to do something more than standard, even something impossible to think of.

\section{The Effect of Self Efficacy toward Job Performance}


Self efficacy is active constructive where a lecturer distinguish his learning aim and try to monitoring, arranging and controling cognition, motivation, and his attitude in order deal with the aim and contextual condition from his environment. Self efficacy is positive manner belonged someone that makes him possible or enable himself to improve perception or positive assesment either to himself or his environment as well as situation he faces. Someone has high self efficacy besed on some aspects with him such as competency, convinced, able, and assure that he does something of his experience, actual potency, achievement, and realistic expectation with himself. This is line with Robert Kreitner and Angelo Kinicki who point out, "In fact, a meta analysis encompassing 21,616 subjects found a significant positive correlation between self efficacy and job performance". Further, Fred Luthans (206) states that whether direct or indirect through other processes, high efficacy is strongly related and very predictive of hich performance. Self efficacy is active constructive where a lecturer distinguishes learning aim and then try to monitoring, arranging, and controling cognition, motivation, and his attitude in order deal with aim and contextual condition from his environment. Based on explanation above, it can be predicted that self efficacy affects directly possitive toward job performance.

\section{The Effect of Self Learning toward Job Performance}

Self learning is very important belonged individual in learning process. Someone with self learning will tend to have a good achievement. This is proved when a lecturer able to distinguish higher academic aim for himself, learn more efective and has achievement at his environment learning, namely Campus. In accordance with Colquitt, LePine and Wesson (2011: 263) state that learning has moderate positive effect on performance. Employees who gain more knowledge and skill tend to have higher levels of Task Performance. Not much is known about the impact of learning on Citizenship Behaviorr and Counterproductive Behavior.

\section{The Effect of Transformational Leadeship toward Self Learning}

Said Achua and Lussier explains that: "A number of study have found that transformational leadership have a strong significant influence on organizational learning. Self learning does not change mental ability, but ability of academic skill. Learning viewed as activity done by lecturer for himself by the way of pro active and not event that happens as reaction of teaching. Self learning refers to self idea, feeling and attitude which orientateds to aim and process used inner to activate, defend idea, attitude, and emotion to gain aim.

\section{The Effect of Transformational Leadership toward Self Learning}

The use effectively of transformational leadership, charisma and authority by leaders is a good way to inspire and motivate their followers to put in trust and obey them. Success leader is a leader who able to be inspirator and motivator for their followers, so that followers have ability to improve themselves by learning, particularly learing indepedently. A line with this, Achua and Lussier (2010: 305) point out that a number of study have found that transformational leadership have a strong significant influence on organizational learning. From this explanation, it can be predicted that transformational leadership effect directly positive toward self learning.

\section{The Effect of Self Efficacy toward Self Learning}

Self afficacy is necessary belonged individual in learning process. Someone with self efficacy will tend to have a good achievement. This is empowered when a teacher has self efficacy will be able to distinguish higher academic aim for himself, work more effectively and get echievement at his learning environment. Dale Scunk et. al. (2008:140) state that self-efficacy was a significant predictor of learning and achievement, even after prior achievement and cognitive skills were taken into consideration. From this explanation predicted that there is any significant relation between sel efficacy and self learning as well as any direct effect positively of self efficacy toward self learning.

\section{The Effect of Transformational Leadership toward Self Efficacy}

Transformational leader has responsibility toward activity done by his subordinates. Leader existance expected able to effect his employee to have self efficacy in running their task.Robbins and Judge (2015: 381,384 ) point out that individual-focused transformational leadership is behavior that empower individual 
followers to develop, change their abilities, and increase self efficacy. Team focused transformational leadership emphasizes group goals, shares values and beliefs and united efforts. Further, it is said that transformational leaders are able to increase followers self efficacy, giving the group a can do spirit. Meanwhile, Gary Yukl defines transformational leadership behavior such as inspirational motivation (e.g. optimistic visioning) and individualized consideration (e.g. coaching) may increase the self efficacy of individual subordinates (Mc Coll Kennedy \&Anderson , 2001) and the collective efficacy of teams (see chapter 10). Intellectual stimulation may increase the creativity of individual followers (Howell \& Avolio, 1993; Keller, 1992; Sosik, Kahai, \& Avolio, 1998).

\section{Research Methods}

This research used quantitative approach with survey method and path analysis technique. The research conducted at Curup City of Rejang Lebong Regency of Bengkulu Province, with analysis unit was lecturers of STAIN Curup. The number of sample taken was 96. Research started from preparing proposal up to research conducted in September 2016 until August 2017. Data collection started from March 2017 until August 2017. Variable of analysis path consisted of exogenous and endogenous variable with research constellation as follows:

figure 1. research constellation

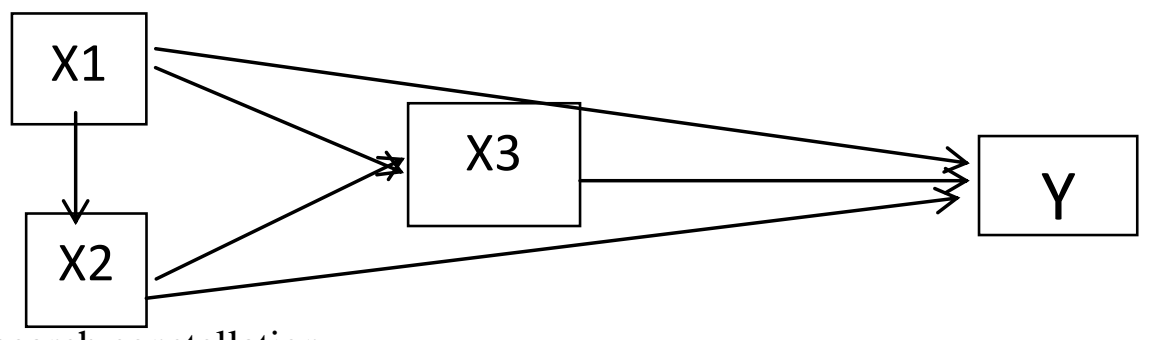

Notes:

$\mathrm{X} 1=$ Transformational Leadership

$\mathrm{X} 2=$ Self Efficacy

$\mathrm{X} 3=$ Self Learning

$\mathrm{Y}=$ Lecturers Job Performance

\section{Result and Discussion \\ Validity and Reliability}

In pilot instrumets took 30 respondents. Validation test of research instrument used Pearson Product Moment Correlation. Validation test of job performance used computer software, Microsoft Excel. Validity of question item stated valid if the value of $r$ calculation $\geq r$ table. The value of $r$ table for $n=30, \alpha=0,05$

Table 1.Validity and Reliability Test Result

\begin{tabular}{|c|c|c|c|c|}
\hline Variable & $\begin{array}{c}\text { Valid } \\
\text { Questions }\end{array}$ & $\begin{array}{c}\text { Invalid } \\
\text { Questions }\end{array}$ & $\begin{array}{c}\text { Alpha } \\
\text { Cronbach Value }\end{array}$ & $\begin{array}{c}\text { Assumption of } \\
\text { Reliability }\end{array}$ \\
\hline Job Performance & 28 & 12 & 0,975 & High \\
\hline $\begin{array}{c}\text { Transformational } \\
\text { Leadership }\end{array}$ & 39 & 1 & 0,974 & High \\
\hline Self Efficacy & 27 & 13 & 0,952 & High \\
\hline Self Learning & 30 & 10 & 0,956 & High \\
\hline
\end{tabular}

Based on description of table 1, it can be seen that all variables have value of Cronbach alpha> $r$ table, it is said reliable.

\section{Linierity and Significant Regression Test}


Linearity test and significant regresive test used SPSS software constants and regresive coeficient linearity obtained from column $\mathrm{B}$ in coeffiient table and possitive effects can be seen by anova table in column $\mathrm{F}$ where $F_{\text {calculation }}>F_{\text {table }}$ and value of sgnificant $p$-value value $<0,05$.

Table 2. Linierity Test and Regeression Significant Test Result

\begin{tabular}{|c|c|c|c|c|c|c|}
\hline \multirow{2}{*}{ Reg } & Persamaan & \multicolumn{2}{|c|}{ Uji Signifikansi } & \multicolumn{2}{|c|}{ Uji Linieritas } & \multirow{2}{*}{ Kesimpulan } \\
\cline { 3 - 6 } & $\mathbf{F}_{\text {hitung }}$ & $\begin{array}{c}\mathbf{F}_{\text {tabel }} \\
\boldsymbol{\alpha}=\mathbf{0 , 0 5}\end{array}$ & $\mathbf{F}_{\text {hitung }}$ & $\begin{array}{c}\mathbf{F}_{\text {tabel }} \\
\boldsymbol{\alpha}=\mathbf{0 , 0 5}\end{array}$ & \\
\hline $\mathrm{Y}$ atas $\mathrm{X}_{1}$ & $\hat{\mathrm{Y}}=70,790+0,113 \mathrm{X}_{1}$ & $5,694^{* *}$ & 3,942 & $1,376^{\mathrm{ns}}$ & 1,656 & $\begin{array}{c}\text { very significant/ } \\
\text { regresi linier }\end{array}$ \\
\hline $\mathrm{Y}$ atas $\mathrm{X}_{2}$ & $\hat{\mathrm{Y}}=56,119+0,276 \mathrm{X}_{2}$ & $9,555^{* *}$ & 3,942 & $1,107^{\mathrm{ns}}$ & 1,627 & $\begin{array}{c}\text { very/ regresi } \\
\text { linier }\end{array}$ \\
\hline $\mathrm{Y}$ atas $\mathrm{X}_{3}$ & $\hat{\mathrm{Y}}=58,213+0,256 \mathrm{X}_{3}$ & $7,483^{* *}$ & 3,942 & $1,613^{\mathrm{ns}}$ & 1,617 & $\begin{array}{c}\text { very signivicant/ } \\
\text { regresi linier }\end{array}$ \\
\hline $\mathrm{X}_{3}$ atas $\mathrm{X}_{1}$ & $\hat{\mathrm{X}}_{3}=79,434+0,138 \mathrm{X}_{1}$ & $7,651^{* *}$ & 3,942 & $0,750^{\mathrm{ns}}$ & 1,656 & $\begin{array}{c}\text { very significant/ } \\
\text { regresi linier }\end{array}$ \\
\hline $\mathrm{X}_{3}$ atas $\mathrm{X}_{2}$ & $\hat{\mathrm{X}}_{3}=48,591+0,474 \mathrm{X}_{2}$ & $30,028^{* *}$ & 3,942 & $1,388^{\mathrm{ns}}$ & 1,627 & $\begin{array}{c}\text { very significant/ } \\
\text { regresi linier }\end{array}$ \\
\hline $\mathrm{X}_{2}$ atas $\mathrm{X}_{1}$ & $\hat{\mathrm{X}}_{2}=80,102+0,139 \mathrm{X}_{1}$ & $7,230^{* *}$ & 3,942 & $0,896^{\mathrm{ns}}$ & 1,656 & $\begin{array}{c}\text { Very significant/ } \\
\text { regresi linier }\end{array}$ \\
\hline
\end{tabular}

Table 3. Matrix of simple coefficient correlation amongs variables

\begin{tabular}{|c|c|c|c|c|}
\hline $\mathbf{R i j}$ & $\mathbf{X}_{\mathbf{1}}$ & $\mathbf{X}_{\mathbf{2}}$ & $\mathbf{X}_{\mathbf{3}}$ & $\mathbf{X}_{\mathbf{4}}$ \\
\hline $\mathbf{X}_{\mathbf{1}}$ & 1,0000 & 0,2670 & 0,2740 & 0,2390 \\
\hline $\mathbf{X}_{\mathbf{2}}$ & 0,2670 & 1,0000 & 0,4920 & 0,3040 \\
\hline $\mathbf{X}_{\mathbf{3}}$ & 0,2740 & 0,4920 & 1,0000 & 0,2720 \\
\hline $\mathbf{X}_{\mathbf{4}}$ & 0,2390 & 0,3040 & 0,2720 & 1,0000 \\
\hline
\end{tabular}

From table 3 can be seen that correlation between transformational leadership and self efficacy in amount of 0,2670. Correlation between transformational leadership and self learning in amount of 0,2740. Correlation between transformational leadership and lecturers job performance in amount of 0,2390. Correlation between self efficacy and self learning in amount of 0,4920. Correlation between self efficacy and lecturers job performance in amount of 0,3040. Correlation between self learning and lecturers job performance in amount of 0,2720 .

a. Dependent Variable: Self Efficacy

\section{Table 4. Coefficient Path on Sub-strucure 1}

Coefficients $^{\text {a }}$

\begin{tabular}{|c|c|c|c|c|c|c|}
\hline \multirow{2}{*}{\multicolumn{2}{|c|}{ Model }} & \multicolumn{2}{|c|}{$\begin{array}{c}\text { Unstandardized } \\
\text { Coefficients }\end{array}$} & \multirow{2}{*}{$\begin{array}{c}\text { Standardized } \\
\text { Coefficients } \\
\text { Beta }\end{array}$} & \multirow[t]{2}{*}{$\mathrm{t}$} & \multirow[t]{2}{*}{ Sig. } \\
\hline & & B & Std. Error & & & \\
\hline \multirow[t]{3}{*}{1} & (Constant) & 44.615 & 8.493 & & 5.253 & .000 \\
\hline & $\begin{array}{l}\text { Transformational } \\
\text { Leadership }\end{array}$ & .077 & .046 & .154 & 1.666 & .039 \\
\hline & Self Efficacy & .435 & .089 & .451 & 4.885 & .000 \\
\hline
\end{tabular}


Form visualization and coefficient value in the path shows as figure bellows:

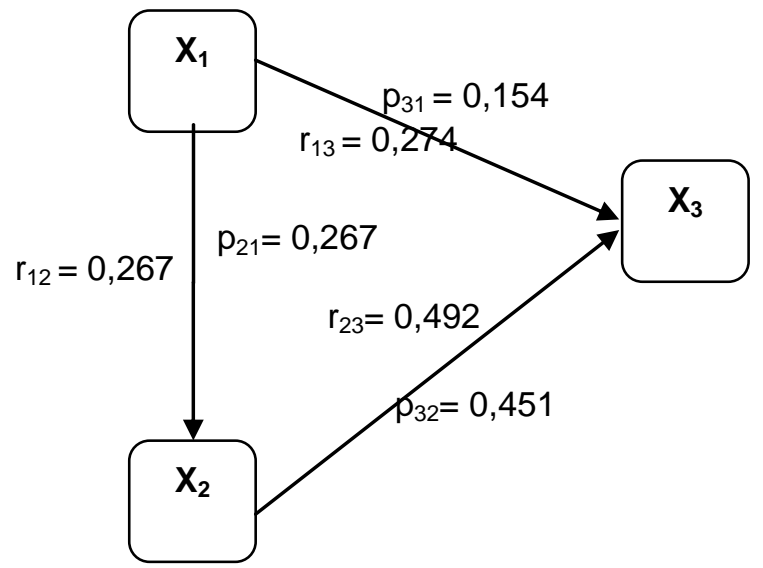

Figure 2. Calculation result of path coefficient on sub-structure 1

On sub-structure 2 consists of 4 variables, they are variable of lecturers job performance $(\mathrm{Y})$ as endogenous variable and exogenous variable is self learning $\left(X_{3}\right)$, self efficacy $\left(X_{2}\right)$ and transformational leadership $\left(\mathrm{X}_{1}\right)$. Therefore, there are three path coefficients which can be known on sub-structure 3, namely path coefficient $Y$ above $X_{1}$ which notationed with $\rho_{41}$, path coefficient $Y$ above $X_{2}$ which notationed with $\rho_{42}$ and path coefficient $Y$ above $X_{3}$ which notationed with $\rho_{43}$.

Furthermore, form of that effect path brings equation of predictive structure with formula: $\hat{\mathrm{Y}}=$ $\rho_{41} X_{1}+\rho_{42} X_{2}+\rho_{43} X_{3}+\rho_{4 \varepsilon}$. The result of calculation by matrix the value of path coefficient $\rho_{41}=0,150, \rho_{42}=$ 0,198 and $\rho_{43}=0,133$. Therefore, equation of predictive structure become $\hat{Y}=0,1501 X_{1}+0,198 X_{2}+$ $0,133 \mathrm{X}_{3}+\rho_{4 \varepsilon}$. It is linear with using SPSS 16.0 which can be seen on table 5 bellows:

Table 5. Coefficient Path on Sub-strucure 2

Coefficients $^{\mathrm{a}}$

\begin{tabular}{|c|c|c|c|c|c|c|}
\hline & \multirow{2}{*}{ Model } & \multicolumn{2}{|c|}{ Unstandardized Coefficients } & $\begin{array}{l}\text { Standardized } \\
\text { Coefficients }\end{array}$ & \multirow{2}{*}{$\mathrm{t}$} & \multirow{2}{*}{ Sig. } \\
\hline & & $\mathrm{B}$ & Std. Error & Beta & & \\
\hline \multirow[t]{4}{*}{1} & (Constant) & 46.384 & 9.960 & & 4.657 & .000 \\
\hline & $\begin{array}{l}\text { Transformational } \\
\text { Leadership }\end{array}$ & .071 & .048 & .150 & 1.462 & .037 \\
\hline & Self Efficacy & .180 & .103 & .198 & 1.756 & .042 \\
\hline & Self Learning & .125 & .107 & .133 & 1.174 & .044 \\
\hline
\end{tabular}

a. Dependent Variable: Job Performance

Lecturer 
Visualization of form and coefficient value on path shows in figure as belows:

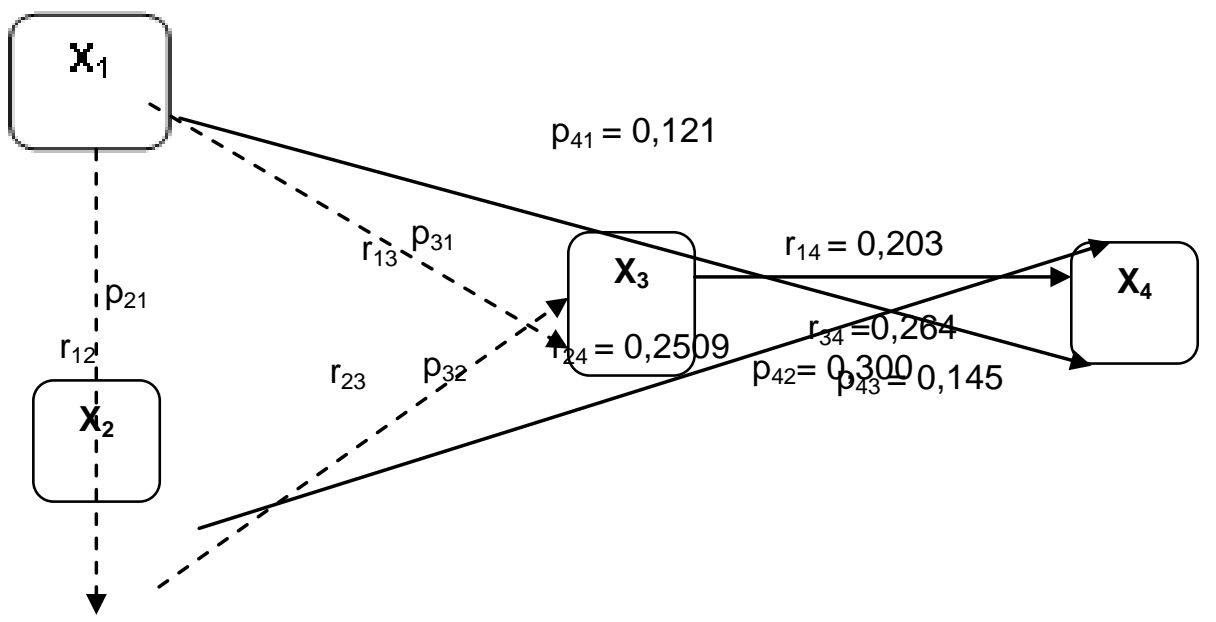

Figure 3. Result Summary of Path Coefficient Test in Research Structure.

Based on the result of equation path analysis on sub-structure 1, 2 and 3 got path coefficient values which shows causal relation in structure model analized.

Coefficient values on figure above can be concluded that all path significant proven that is $\mathrm{Y}$ above $\mathrm{X} 1$ ( $\rho 41)$, Y above X2 ( $\rho 42), Y$ above X3 ( $\rho 43), X 3$ above X1 ( $\rho 31), X 3$ above X2 ( $\rho 32$ ), and X2 above X1 $(\rho 21)$. Therefore, structure model shown in this research does not need modified.

\section{Discussion}

Based the result of model testing that has been done in this research (linearity evaluation model with data) obtained proper linearity level, so that model constructed is avaiable to be used to test research hypothesis and then obtained the result of research hypothesis test. As basis of hypothesis test result that has been done so displayed discussion of hypothesis test result of the research. As a whole, there are six hypothesis tested in this research and proven these six hypothesis show linear correlation and significant effect, these are $\mathrm{Y}$ above $\mathrm{X} 1, \mathrm{Y}$ above X2, $\mathrm{Y}$ above X3, X3 above X1, X3 above X2 and X2 above X1.

Based on research result that has conducted to the lecturers at STAIN Curup (96 lecturers of civil servant), it can be concluded as follows: 1) transformational leadership effects directly positive toward lecturers job performance of STAIN Curup.It means that a strong transformational leadership will cause job performance improvement to lecturers of STAIN Curup, this is a line with previous research conducted by Jyoti and Bhau (2015:6) who stated that furthermore the RI does not as a mediator between the transformational leadership and job performance but it act as moderator and strengthens the relationship between TL and JP. 2) self efficacy effects directly positive toward lecturers job performance of STAIN Curup. It means that high self efficacy will cause job performance improvement to lecturers of STAIN Curup, this is the same with the previous research conducted by Muhammad Slaman, Nazar Khan, Umer Draz, Iqbal and Kamran Aslam (2016: 141) who pointed out that the results indicate that self efficacy has significant relationship with job performance factors. The result shows that self efficacy has significant correlation with the factor of job performance task. 3) self learning effects directly positive toward lecturers job performance of STAIN Curup. It means that high self learning will cause job performance improvement to lecturers of STAIN Curup, it is similar with previous relevant research conducted by Dayagbil (2013:439-440) which found that there is an effect of self learning toward job performance, where analysis unit he conducted for was 6 educational institutions at Chien-Chi Tseng. He then said that by understanding the nature of self-directed learning through which it affects entrepreneurial learning, this research contributes insights into the effectiveness of entrepreneurial processes and can thus provide practical implications for individuals and enterprises to establish entrepreneurial performance. Consequently, the proposed framework offers pedagogical implications of self-directed learning on supporting entrepreneurial learning and performance in the future study. Independent learning to support enterpreneurial learning and job performance in Indonesia the study for future. Wang (2008) in Chien in general also stated that there is any positive correlation between self learning and job performance. The research result shows that human is never stop for learning. 
Learning done particularly is learning shown for himself can be separated from self maturity that obtained from self conception. Self conception is such mental ecquipment which drives human in his mind set, giving consiousness. Self consciousness drives human to learn always especially to himself. This such mind set makes someone belongs to self learning, so that such mind set can be said core of self learning. 4) transformational leadership effects directly positive toward self learning. It means that strong transformational leader will cause self learning improvement to the lecturers of STAIN Curup, a line with previous research conducted by Mesterova, Prochazka and Vaculik pointed out that there is any correlation and effect between transformational leadership andself learning. 5) Self efficacy effects directly positive toward transformational leadership. It means that lecturers with high self efficacy will cause transformational leadership improvement, this is similar with the research conducted by Shih-Hsiung Liu who stated that students sel efficacy in educational teacher have effect directly and significant toward independent learning activity with high statistical effect.6) Transformational leadership effects directly toward self efficacy. It means that a good transformational leadership will cause self efficacy improvement, this is a line with the research conducted by Jyoti Anggrawal and Ventkant Khrisnan who stated that their research result shows any positive between transformational leadership and self efficacy progress. Management strategy focuses on self positive impession correlates with self efficacy.

\section{Conclusion}

Based on previous research and theory, it shows that there are many factors that effect job performance, such as commitment, work ethos, belief, cultural work, work climate, transformational leadership, self efficacy and self learning. However, researcher only conducted research on three variables which mobilize lecturers job performance at STAIN Curup becomes good and productive so that all tasks given to them by the head of study program can be actualized well. Novelty from this research from others researcher is research model which search about lecturers job performance viewed from the effect of transformational leadership factor (indicators: effectivity, productivity, and usefullnes), self efficacy factor (indicators: mobilize motivation, cognitive resources, task difficulty level, and attitude selection) andself learning (indicators: self assesment, self improvement and self reinvorcement). In this research, endogenous variable is lecturers job performance (Y) and intervening variable is self learning (X3) and self efficacy (X2), whereas exogenous variable is transformational variable (X1). Based on the research result which has been conducted to the lecturers of STAIN Curup (96 lecturers) obtained research conclusion: 1) transformational leadership effects directly positive toward lecturers job performance at STAIN Curup. It means that a strong transformational leadership will cause job performance improvement to the lecturers of STAIN Curup, 2) self efficacy effect directly positive toward lecturers job performance of STAIN Curup. It means that a high self efficacy will cause job performance improvement to the lecturers of STAIN Curup, 3) self learning effects directly positive toward lecturers job performance of STAIN Curup. It means that a high self learning will cause job performance improvement to the lecturers of STAIN Curup, 4) transformational leadership effects directly positive toward self learning. It means that a strong transformational leadership will cause self learing improvement to the lecturers of STAIN Curup, 5) self efficacy effects directly positive toward transformational leadership. It means that alecturer with high self efficacy will cause transformational leadership improvement and 6) transformational leadership effects directly positive toward self efficacy. It means that a good transformational leadership will cause self efficacy improvement.

\section{References}

[1] Colquitt, LaPine dan Welson.Organizational Behavior. Fourth Edition (United States: McGraw Hill International, 2011

[2] Chien Chi Tseng. Connecting Self-Directed Learning With Enterpreunerial Learning To Entrepreuneurial Performance. International Journal Of Entrepneurial Behavior \& Research Vol 19 No 4. Florida: Emerald, 2013

[3] Christopher F Achua and Robert N. Lussier, Effective Leadership ,Canada: Cengange Learning, 2010

[4] Soane, Emma et.al., Follower Personality Transformational Leadership And Performance. Sport Business and Management (London: Emerald. An Internationaal Journal Vol.5 No 1, 2015

[5] Luthans, Freds. Organizational Behavior. 12 Edition New York: Mc Graw Hill Irwin, 2010 
[6] Yukl, Gary. Leadership in Organization, fifth edition New Jersey: Prentice-Hall Inc, 2001

[7] Gibson, et.al., Organizations. Behavior, Structure and Processes (New York: Mc Graw Hill, 2011

[8] Gibson, Donnely, Ivancevich and Konopaske. Organizational Behavior, Structure, Process (New York: McGraw-Hill, 2012

[9] Ivancevich dkk.Organizational Behavior \& Management.Tenth Edition. (North American: McGraw Hill International Edition, 2014

[10] Jennifer M George and Gareth R Jones.Organizational Behavior.Fourth Edition. (New Jersey: Pearson Prentice Hall, 2005

[11] Jex and Britt.Organizational Psycology Second Edition. (New Jersey: John Wiley \& Sons, 2008

[12] Jyotti and Bhau.Impact Transformational Leadership on Job Performance. Mediating Role of Leader Member Exchange and Relationship Identification (Sage Open, 2015

[13] Muhammad Slaman et. al. Impact of Self-Efficacy on Employee's Job Performance in Health Sector of Pakistan (Amerika: American Journal of Business and Society Vol. 1, No. 3, pp. 136-142, 2016

[14] Richard L Daft. The Leadership Experience USA: Cengage Learning, 2015

[15] Robert Kreitner and Angelo Knicky, Organizational Behavior. New York: Mc.Graw Hill, 2010

[16] Rue, Ibrahim dan Byars. Human Resources Management.New York: McGraw-Hill Companies, Inc, 2008

[17] Sharon. Encouraging Self-Regulated Learning inthe Calssroom.A Review Literatur. (Virginia: Metropolitan Educational Research Consortium (MERC), 2011

[18] Schermerhorn and Osborn, et.al.,Organizational Behavior. Hoboken: John Wiley \& Sons, 2012

[19] Schunk, et.al., Motivation in Education, (New Jersey: Pearson Menrill Prentice Hall, 2008

[20] Shani, et.al., Behavior Organization, (North America: McGraw Hill, 2009

[21] Shih-Hsiung Liu.Effects of Self-Perceptions on Self-Learning among Teacher Education. International Education Studies; Vol. 8, No. 10; Canada: Canadian Center of Science and Education, 2015

[22] Stephen L McShane and Glinov.Organizational Behavior.Emerging Knowledge, Global Reality.Seventh Edition.North America: McGraw Hill, 2015

[23] Robbins, Robbin and Judge, Organizational Behavior, Fourteenth Edition (England: Pearson Education Limited, 2010

[24] Jayawheera, Thusthel. Impact of Work Environmental Factors on Job Performance. Medating Role of Work Motivation: A Study of Hotel Sector in England (Canada: International Journal of Business and Management, Vol 10 No 3, 2005) 